\title{
COMPARATIVE ANALYSIS OF FOREST PLANTATIONS CUTTING AGE BASED ON VOLUMETRIC AND GRAVIMETRIC UNITS
}

\author{
Priscila Dini Coelho ${ }^{1}$, Gabriel Browne de Deus Ribeiro ${ }^{1 *}$, Crismeire Isbaex $^{1}$, Lorena Castro Ribeiro ${ }^{1}$, Sebastião \\ Renato Valverde ${ }^{1}$
}

${ }^{1}$ Federal University of Viçosa, Department of Forest Engineering, Viçosa, Minas Gerais, Brazil, prissdini@gmail.com; gabrielbrowne@gmail.com*; engisbaex@gmail.com; lorena.castro@aperam.com; valverde@ufv.br

Received for publication: 24/04/2017 - Accepted for publication: 16/04/2019

\begin{abstract}
Resumo
Análise comparativa da idade de corte de plantações florestais com base em unidades volumétricas e gravimétricas. O objetivo deste trabalho foi avaliar a idade técnica e econômica de corte de plantações florestais considerando o mercado de madeira sob as unidades de medida volumétrica e gravimétrica. Foram obtidos dados de uma empresa florestal na região do Jequitinhonha, Minas Gerais, de produção volumétrica e densidade básica da madeira para povoamentos de clones de Eucalyptus urophylla, nas idades de 3 a 9 anos. Foram estimados: massa por hectare; idade técnica de corte (ITC) para volume e massa; e viabilidade econômica em diferentes taxas de juros. Os dados foram divididos por três clones, do mais denso (C), passando por (B), com densidade intermediária, ao menos denso (A). Os resultados demonstraram que em se alternando a unidade de análise de volumétrica para gravimétrica, a ITC ocorre pelo menos um ano mais tarde. Nas análises econômicas, os resultados evidenciaram que projetos destinados a comercialização da madeira por medida gravimétrica são viáveis economicamente quando utilizados clones de alta densidade, devido a maior quantidade de massa por volume. Já para clones com baixa densidade e alta produtividade volumétrica, a análise deve ser feita do ponto de vista volumétrico, onde os resultados econômicos foram $23 \%$ superiores que nas análises considerando a massa. Foi concluído que a adoção da unidade de medida gravimétrica no setor florestal tende a provocar mudanças significativas na gestão dos projetos, melhorar as características da madeira para energia pelo adiamento da idade de corte e tornar mais criteriosa a escolha do material genético.

Palavras-chave: biomassa florestal; densidade; volume; análise econômica.
\end{abstract}

\begin{abstract}
The objective of this work was to evaluate the technical and economic cutting age of forest plantations considering the wood market under volumetric and gravimetric measurement units. Volumetric production and wood basic density for Eucalyptus urophylla clones stands were obtained from a forest company in the Jequitinhonha's region, Minas Gerais State, for ages of 3 to 9 years. It was estimated: mass per hectare; technical cutting age (TCA) for volume and mass; and economic viability at different interest rates. Data was divided by three clones, being the denser (C), passing through (B) median density, and less denser (A). The results showed that in alternating volumetric for gravimetric unit, the TCA occurs at least one year later. For the economic analysis, the results demonstrated that projects for wood commercialization by gravimetric measurement are economically viable when using high-density clones, due to the higher amount of mass per volume. For clones with low density and high volumetric productivity, the analysis must be done from a volumetric point of view, as the economic results were $23 \%$ higher than in the mass analysis. It was concluded that the adoption of the gravimetric unit of measure in the forest sector tends to cause significant changes in project management, improving wood characteristics for energy by postponing the cutting age and making more sensible the genetic material selection.

Keywords: forest biomass; density; volume; economic viability.
\end{abstract}

\section{INTRODUCTION}

The Brazilian forest-based productive sector has been experiencing significant changes in the timber market, and these changes have affected both pulp industries and charcoal steel mills, as well as forest producers. Even under expansion, pulp industries have suffered economic losses when consuming wood from long distances and with distinct characteristics. On the other hand, charcoal steel industries are still standing the effects of the 2008 financial crisis, although it was possible to identify an initial reaction of the pig iron production sector in 2018 (IBÁ, 2016; PAINEL FLORESTAL, 2018; VALVERDE et al., 2014).

As an alternative, the wood market has been directed for thermal and power generation through the use of firewood and, mainly, woodchips of Eucalyptus genus (NASCIMENTO; BIAGGIONI, 2010; TORRES et al., 2016). According with the Brazilian Energy Research Company' report (EPE, in Portuguese), it is estimated that 
the Brazilian demand for forest biomass for energy tends to increase over the next 20 years. However, the supply of forest plantations for energy is still incipient to meet the expected demand (EPE, 2016).

One of the main energy properties that industries have considered to implement forest biomass projects is the higher wood density, intrinsic to other desirable properties such as calorific value (VITAL et al., 2013). Some studies have analyzed the variables that most influence the obtaining of densest wood and some indicated that the plantations growth greatly affects the wood properties (CARNEIRO et al., 2014). This means that adult forest plantings will result in higher mass per unit area, which is not consistent with rotations current adopted, which are based on maximum volumetric productivity.

The observed trend of the market interested in biomass for energy is that they tend to consider the unit that measures the desired characteristic, which in this case is the wood mass. For the steel industry, this would be a good practice and could result in more systematic and productive processes (VALE et al., 2011). Though, most of the non-vertical steelmakers still use the volume-based trading model, i.e., the payment is made by volume. In this case, lighter and faster-growing wood is more rated, and production in the blast furnace could be compromised.

It should be noted that plantations that exceed the most common cutting age, at seven years old, can lead to economic losses from a volumetric point of view, as they may exceed the maximum yield peak, defined as the technical cutting age (TCA). However, from the gravimetric point of view, economic viability studies are necessary considering mass production.

Therefore, this paper aimed to analyze the effects of changing the wood measurement unit from volumetric to gravimetry and its consequences on the optimal forest plantations cutting age. To this end, the density effect on the economic analysis at different interest rates was simulated; the differentiated remuneration for those who produce denser wood was also evaluated, in order to provide information that would support the decision making for new investments in eucalyptus forest plantations for biomass production.

\section{MATERIAL AND METHODS}

For the development of this work, data from Eucalyptus urophylla clone stands were used (aged 3 to 9 years) from commercial plantations belonging to a forestry company located in the Jequitinhonha's region, Minas Gerais State, Brazil.

\section{Study area}

The commercial plantations are located in the Jequitinhonha Valley region, west and north of the Espinhaço Mountains, with altitudes ranging between 600 and 1,000 meters. Climate is classified as subtropical humid sub-humid. Mean annual temperature ranges from 19 to $20{ }^{\circ} \mathrm{C}$, and average precipitation from 1,150 to $1,450 \mathrm{~mm}$, as well as a period of 4 to 6 months of drought with a water deficit of 60 to $120 \mathrm{~mm}$ per year. Potential evapotranspiration ranges from 900 to $1,100 \mathrm{~mm}$. Region's predominant soils are ferric luvisols and sandy soils and the predominant forest typology is the cerrado (a savannah-like ecosystem) with its different types (from cerradões to fields), with small occurrences of semi-deciduous and deciduous forests, especially in limestone outcrops (GOLFARI, 1975).

\section{Data source}

The data used in this study was based on a set of permanent plots allocated for growth and yield studies. The adopted spacing was $6 \mathrm{~m} \times 1.5 \mathrm{~m}$ and the age classes ranged from three to nine years. Three Eucalyptus urophylla clones (named A, B and C) were selected and from each clone the mean yield values for each of the age classes were determined, i.e. seven average yield values (in $\mathrm{m}^{3} / \mathrm{ha} / \mathrm{year}$ ) per clone, one value for each age.

For each clone, volume and mean annual increment (MAI) were measured at three to nine years old, and basic density at seven years old. The values were converted into mean values per clone. These were classified as: clone A - with high volumetric productivity (MAI) and low density; clone C - low MAI and high density; and clone B - intermediate. Table 1 shows the mean values of basic density, productivity and volume observed by clone at seven years.

Table 1. Data classification per clone at seven years.

Tabela 1. Classificação dos dados por clone aos sete anos.

\begin{tabular}{lccc}
\hline Classification & Basic density $\left(\mathbf{k g} / \mathbf{m}^{\mathbf{3}}\right)$ & MAI $\left(\mathbf{m}^{\mathbf{3}} \mathbf{/ h a} / \mathbf{y e a r}\right)$ & Volume $\left(\mathbf{m}^{\mathbf{3}} / \mathbf{h a}\right)$ \\
\hline A & 468 & 40.0 & 279.55 \\
B & 520 & 39.0 & 273.06 \\
C & 578 & 30.3 & 212.05 \\
\hline
\end{tabular}

Source: Data obtained from the forestry company. MAI = Mean Annual Increment. 


\section{Wood mass determination}

Basic density was obtained only at seven years old, when the company practices cutting. Therefore, the real density variation of these clones over their ages could not be observed. However, as a simulation for technical and economic analysis, a literature review was made to understand how the basic density of eucalyptus wood increases over the years.

As wood basic density is a changing property, the increase in density was simulated in four increments: $2.0 \%, 3.0 \%, 4.0 \%$ and $5.0 \%$ per year. Such increments were based on the mean values found by Carneiro et al. (2014) and Trugilho et al. (2009) for eucalyptus clones, including E. urophylla. To estimate the mass of wood produced, the volume was multiplied by the basic density, according to the equation:

$$
M_{i}(k g)=V_{i}\left(\frac{m^{3}}{h a}\right) x B D_{i}\left(\frac{k g}{h a}\right)
$$

where, $\mathrm{M}_{\mathrm{i}}=$ mass at age $\mathrm{i}$, in $\mathrm{kg} ; \mathrm{V}_{\mathrm{i}}=$ volume at age $\mathrm{i}$, in $\mathrm{m}^{3}$; and $\mathrm{BD}_{\mathrm{i}}=$ basic density at age $\mathrm{i}$, in $\mathrm{kg} / \mathrm{m}^{3}$.

\section{Technical cutting age determination}

MAI and CAI (current annual increment) were calculated based on volume. TCA (technical cutting age) was obtained by the formula MAI equal to CAI, where there was the highest volumetric productivity (Figure 1):

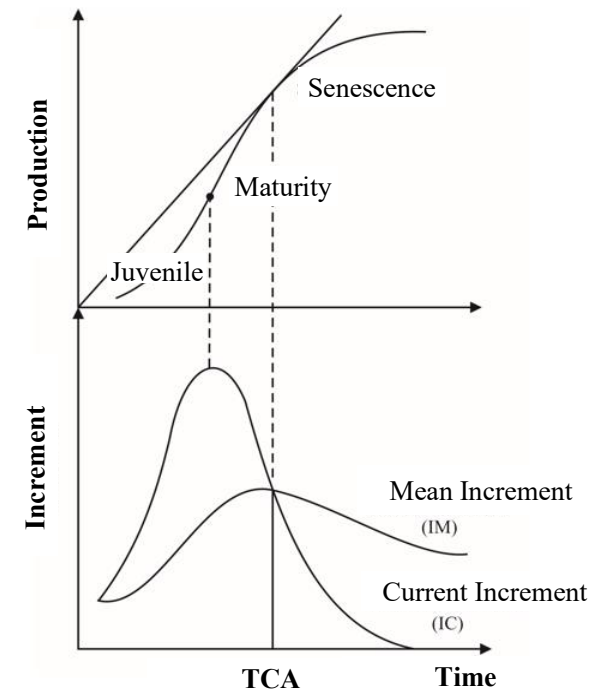

Figure 1. Relation between increment and production in forest stands.

Figura 1. Relação entre incremento e produção em povoamentos florestais equiâneos.

Source: Adapted from Campos and Leite (2013)

With the values of mass produced, MAI and CAI were calculated based on mass (as it was made for volume), for the three clones and for each increment in density. From these values, TCA (technical cutting age) was determined, where there was the highest gravimetric productivity (mass).

\section{Expenses and revenues}

To determine eucalyptus stands' economic rotation, the forestry company made available the approximate expenses related to the implementation activities (soil preparation, planting, seedlings, fertilization, etc.) and maintenance activities (ant fighting, weeding, technical support, etc.), as can be seen in Table 2 .

Table 2. Approximate implementation and maintenance expenses of eucalyptus plantations. Tabela 2. Despesas aproximadas de implantação e manutenção de povoamentos de eucalipto.

\begin{tabular}{lccc}
\hline Year & Activity & Unit & Expenses \\
\hline 0 & Implementation & $\mathrm{R} \$ /$ ha & $3,525.00$ \\
1 & Maintenance & $\mathrm{R} \$ /$ ha & 481.00 \\
2 & Maintenance & $\mathrm{R} \$ / \mathrm{ha}$ & 328.00 \\
3 & Maintenance & $\mathrm{R} \$ / \mathrm{ha}$ & 328.00 \\
\hline
\end{tabular}

FLORESTA, Curitiba, PR, v. 49, n. 4, p. 597 - 606, out/dez 2019.

Coelho, P. D. et.al.

DOI: $10.5380 /$ rf.v49 i4.52043 


\begin{tabular}{llll}
4 & Maintenance & $\mathrm{R} \$ / \mathrm{ha}$ & 328.00 \\
5 & Maintenance & $\mathrm{R} \$ / \mathrm{ha}$ & 328.00 \\
6 & Maintenance & $\mathrm{R} \$ / \mathrm{ha}$ & 328.00 \\
7 & Maintenance & $\mathrm{R} \$ / \mathrm{ha}$ & 328.00 \\
8 & Maintenance & $\mathrm{R} \$ / \mathrm{ha}$ & 328.00 \\
9 & Maintenance & $\mathrm{R} \$ / \mathrm{ha}$ & 328.00 \\
\hline
\end{tabular}

Source: Data obtained from the forestry company, base: second semester of 2016

Gross revenues were obtained by simulating the sale of standing wood, i.e., the harvesting costs were not contemplated. For the sales based on volume, the price adopted was $\mathrm{R} \$ 50.00 / \mathrm{m}^{3}$ and for sales based on mass, $\mathrm{R} \$$ 100.00 /ton, which were prices practiced by the forestry company at the end of 2016. Direct relation considering the mean basic density of $500 \mathrm{~kg} / \mathrm{m}^{3}$.

\section{Economic analysis}

After obtaining volume and mass productivities considering the basic density variations over the years, the cash flow and financial analysis were calculated simulating interest rates of $6.0 \%, 8.0 \%, 10.0 \%, 12.0 \%$ and $14.0 \%$.

Net Present Value (NPV) and Internal Rate of Return (IRR) were used in the economic analysis. These criteria are widely used in the forestry sector and consider the capital over time, thus giving different weights to net revenues over their temporal occurrences (CORDEIRO et al., 2010; SILVA et al., 2005).

NPV evaluates the potential of an investment' value generation. When it is greater than zero, the investment provides an additional value to the investor considering the return of the employed capital, corrected to the considered attractiveness rate (SILVA; FONTES, 2005).

However, as they analyze projects of different durations, which bring changes in cash flow, and consequently in NPV, Rezende and Oliveira (2000) state that an alternative to balance the horizons of projects with different durations is to use the NPV considering the project replication for an infinite horizon $(\mathrm{NPV} \infty)$ according to the equation:

$$
N P V \infty=\frac{N P V(1+i)^{t}}{(1+i)^{t}-1}
$$

where:

$$
N P V=\sum_{j=0}^{n} R_{j}(1+i)^{-j}-\sum_{j=0}^{n} C_{j}(1+i)^{-j}
$$

where: $\mathrm{Rj}=$ revenues at the end of the year or at $j$ period considered; $\mathrm{Cj}=$ costs at the end of the year or at $j$ period considered; $j=$ period of revenues or costs occurrence $(0, \ldots, \mathrm{n}) ; n=$ project duration in years or in numbers of time periods; $i=$ annual interest rate expressed in unit form.

Where NPV $\infty$ is the calculated net present value considering the project replication to an infinite horizon; $\mathrm{n}$ is the project duration in years, or numbers of time period, and NPV is the net present value of the project.

Similar to NPV, the project that presents NPV $\infty$ greater than zero (positive) is economically viable, being considered the best one with the highest NPV $\infty$. To use this method, it is also necessary to define a discount rate $i$ (SILVA; FONTES, 2005).

IRR corresponds to the annual rate of return of the invested capital and is also the discount rate that equals the present value of revenues with the present value of costs (REZENDE; OLIVEIRA, 2001). It is, therefore, the rate that nullifies the NPV (SILVA et al., 2005). In addition, IRR can also be understood as the percentage rate of return of the invested capital. Equation:

$$
\sum_{j=0}^{n} R_{j}(1+I R R)^{-j}=\sum_{j=0}^{n} C_{j}(1+I R R)^{-j}
$$

One project will be economically viable if its IRR is higher than a discount rate corresponding to the alternative capital return rate, usually called as the minimum attractive rate of return (MARR). 


\section{RESULTS}

Comparative of the genetic material choice considering the volumetric and gravimetric units

The values of basic density, volumetric MAI and estimated mass at seven years are shown in Graph 1.

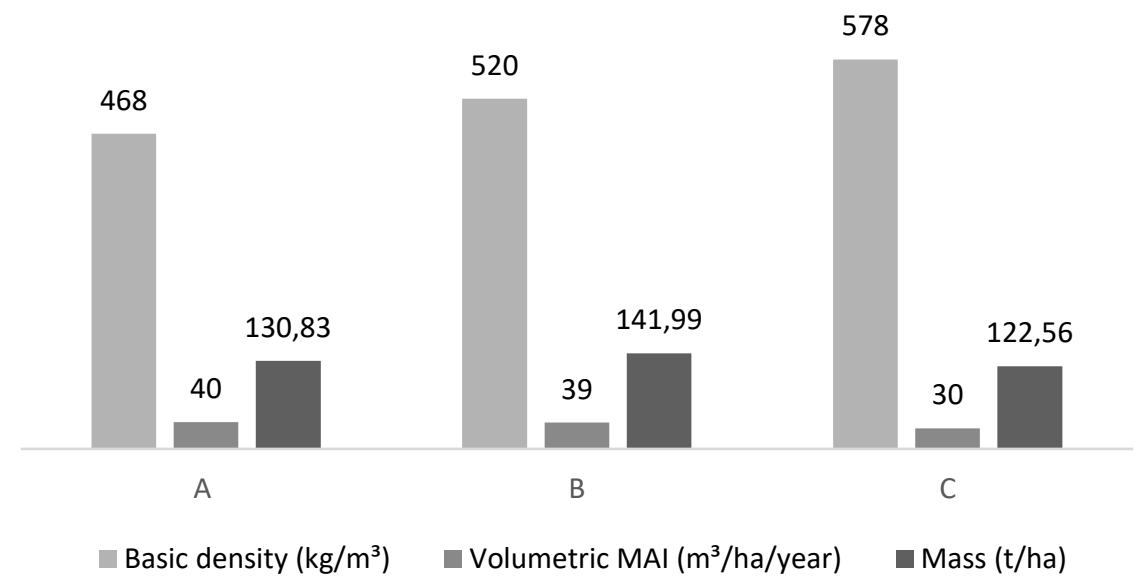

Graph 1. Basic density, volumetric MAI and estimated mass of clones A, B and C in year 7.

Gráfico 1. Densidade básica, IMA volumétrico e massa estimada dos clones A, B e C no ano 7.

It is observed that if the producer' decision making in relation to its market is only volumetric, the decision would be for clone A, since it is the one that has the highest productivity (MAI), resulting in higher wood volume per hectare. If the unit employed in forestry trading is the volumetric unit $\left(\mathrm{R} \$ / \mathrm{m}^{3}\right)$, this implies that this clone will give the best financial return to the producer. Otherwise, if it was commercialized by mass, the choice would initially be for clone B because its mass production is higher even presenting intermediate density in relation to the others.

\section{Obtaining the technical cutting age - volumetric}

Forests conducted from rotations that maximize MAI result in the production of more wood per unit time and per unit area. In this case, age is defined regardless of economic issues. According to the results presented in the graphs of Figure 2, it is observed that the technical cutting age based on volume was six years for clone A, five for $\mathrm{B}$ and seven for clone $\mathrm{C}$ - ages in which they presented maximum volumetric productivity.

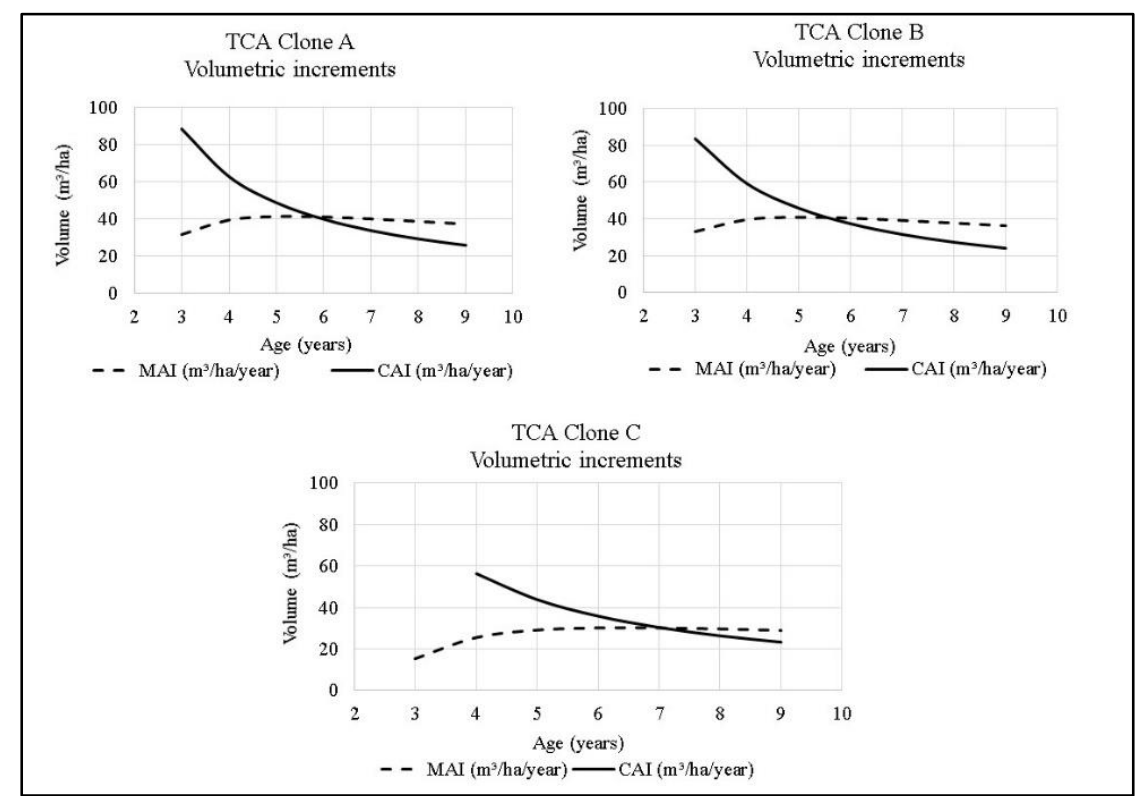

Figure 2. Mean (MAI) and current (CAI) annual volumetric increments for clones A, B and C. Figura 2. Incrementos volumétricos médio e corrente anual para os clones A, B e C. 


\section{Obtaining the technical cutting age - gravimetric}

Considering the gravimetric unit (wood mass), a significant difference was observed in the TCA in relation to the volumetric unit due to the variation of density (increments). From the four simulations of percentage increases in basic density $(2,3,4$ and $5 \%$ per year), the greater the increase in density, the more the TCA is postponed, according to the results in Table 3.

Table 3. Summary of TCA results for volume and mass by clone.

Tabela 3. Resumo dos resultados da ITC em volume e massa por clone.

\begin{tabular}{cccccc}
\hline Clone & $\begin{array}{c}\text { TCA } \\
\text { volume } \\
\text { (years) }\end{array}$ & $\begin{array}{c}\text { 2\% mass } \\
\text { increment }\end{array}$ & $\begin{array}{c}\text { 3\% mass } \\
\text { increment }\end{array}$ & $\begin{array}{c}\text { 4\% mass } \\
\text { increment }\end{array}$ & $\begin{array}{c}\text { 5\% mass } \\
\text { increment }\end{array}$ \\
\hline A & 5 & 6 & 7 & 9 & $>9$ \\
B & 6 & 6 & 6 & 8 & 9 \\
C & 7 & 8 & 9 & $>9$ & $>9$ \\
\hline
\end{tabular}

Economic analysis - economic cutting age (volumetric)

The economic analysis for the sale of wood by volume for the clone A presented the same results for all interest rates, and the cutting age that provided the greatest economic viability was at six years. Therefore, for the forest producer that sells wood by volume, within the interest rate range of 6 to 14\% p.a., the most viable option was to cut at six years for clone A. The same results were observed for clone B.

Clone $\mathrm{C}$ has presented different economic behavior. Due to its lower volumetric productivity, NPV became negative when the discount rate exceeded $10 \%$. At rates of 6 and $8 \%$, the highest economic viability for this clone was the cut at 8 and 7 years, respectively. The results can be seen in the graphs of Figure 3.

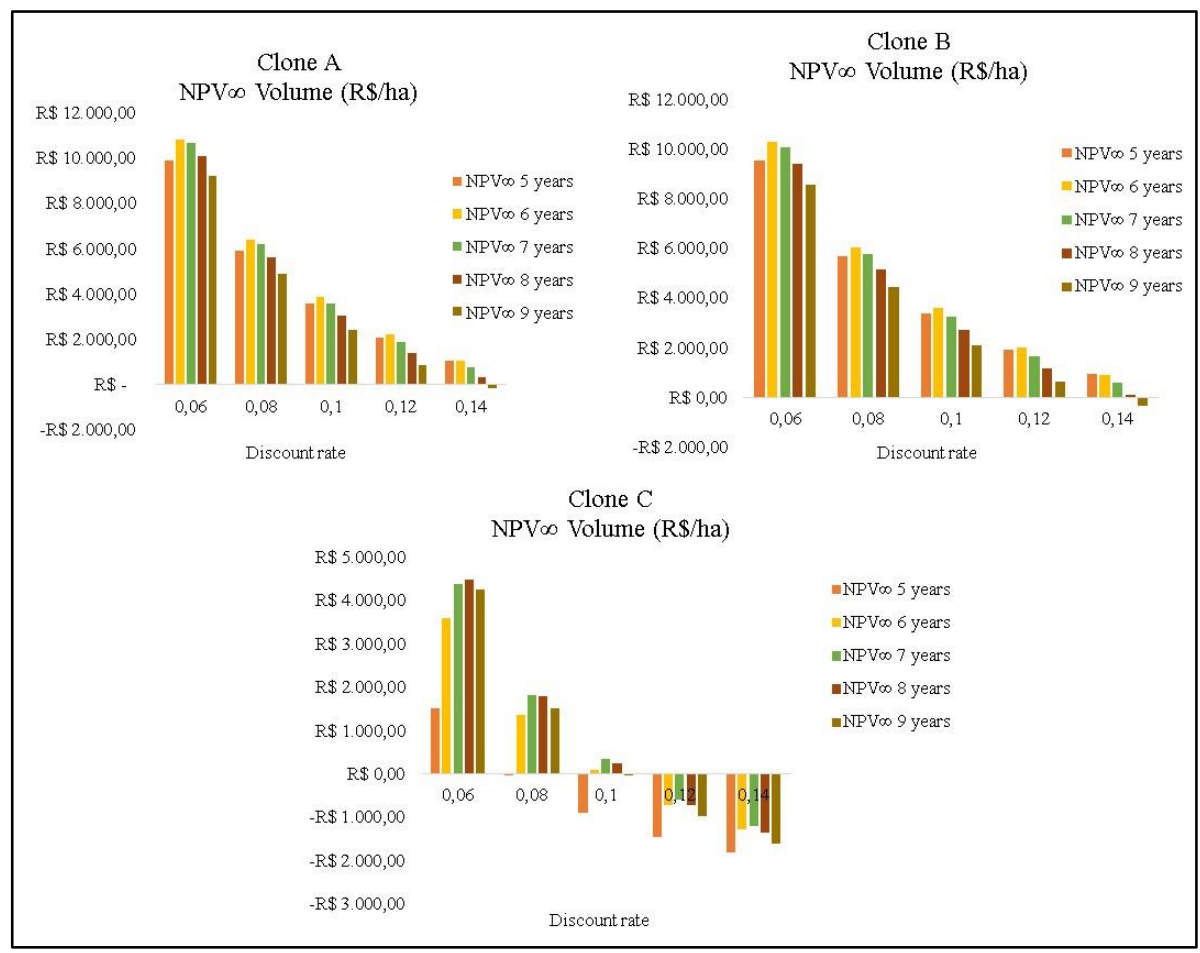

Figure 3. Volumetric NPV results for clones A, B and C.

Figura 3. Resultado do VPL volumétrico para os clones A, B e C.

\section{Economic analysis - economic cutting age (gravimetric)}

The economic analysis for wood sales in mass showed that the economic cutting age is postponed by at least one year compared to the economic analysis by volume. The results of economic cutting ages are summarized in Table 4.

Considering the density increase rate of $2 \%$, clone A presented maximum NPV $\infty$ at seven years up to $10 \%$ discount rate, and at six years at $12 \%$ and $14 \%$ rates. Clone B had a maximum NPV $\infty$ at seven years for rates 
up to $8 \%$, and six years for $10 \%$ to $14 \%$. Clone $\mathrm{C}$, for the same increase in density, demonstrated the maximum NPV $\infty$ at eight years at rates up to $10 \%$, seven years at $12 \%$, and was unviable at $14 \%$.

Table 4. Economic cutting age on volumetric and gravimetric analysis, by interest, by clone.

Tabela 4. Idade econômica de corte pela análise volumétrica e gravimétrica, por taxa de juros, por clone.

\begin{tabular}{|c|c|c|c|c|c|}
\hline \multirow{2}{*}{ Clone } & \multicolumn{5}{|c|}{ Interest rate } \\
\hline & $6 \%$ & $8 \%$ & $10 \%$ & $12 \%$ & $14 \%$ \\
\hline \multicolumn{6}{|c|}{ Volume } \\
\hline $\mathbf{A}$ & 6 & 6 & 6 & 6 & 6 \\
\hline B & 6 & 6 & 6 & 6 & 5 \\
\hline $\mathbf{C}$ & 8 & 7 & 7 & - & - \\
\hline \multicolumn{6}{|c|}{ Mass - 2\% increment } \\
\hline $\mathbf{A}$ & 7 & 7 & 7 & 6 & 6 \\
\hline B & 7 & 7 & 6 & 6 & 6 \\
\hline C & 8 & 8 & 8 & 7 & - \\
\hline \multicolumn{6}{|c|}{ Mass $-3 \%$ increment } \\
\hline $\mathbf{A}$ & 8 & 7 & 7 & 7 & 6 \\
\hline B & 8 & 7 & 7 & 6 & 6 \\
\hline $\mathbf{C}$ & 9 & 9 & 8 & 8 & - \\
\hline \multicolumn{6}{|c|}{ Mass $-4 \%$ increment } \\
\hline $\mathbf{A}$ & 9 & 8 & 7 & 7 & 7 \\
\hline B & 8 & 8 & 7 & 7 & 6 \\
\hline $\mathbf{C}$ & 9 & 9 & 9 & 8 & - \\
\hline \multicolumn{6}{|c|}{ Mass $-5 \%$ increment } \\
\hline $\mathbf{A}$ & 9 & 9 & 8 & 8 & 7 \\
\hline B & 9 & 8 & 8 & 7 & 7 \\
\hline C & 9 & 9 & 9 & 9 & - \\
\hline
\end{tabular}

To validate the gravimetric unit importance in economic analysis, the three clones were analyzed under the same 8\% interest rate scenario (Figure 4). It was observed for clone A, which presents high volumetric productivity and low density, that the change in the measurement unit is not interesting, in which the volumetric NPV $\infty$ was higher than the gravimetric in practically all scenarios. Concerning the cutting age, considering the $8 \%$ rate, clone A would be cut at the highest NPV $\infty$ point at five years.

For clones $\mathrm{B}$ and $\mathrm{C}$, which presented higher density, gravimetric analyses were better for this case, with higher gravimetric NPV $\infty$ in almost all scenarios. For these clones, the difference in volumetric to gravimetric analysis is $12 \%$ for clone $\mathrm{B}$, and up to $152 \%$ for clone $\mathrm{C}$.

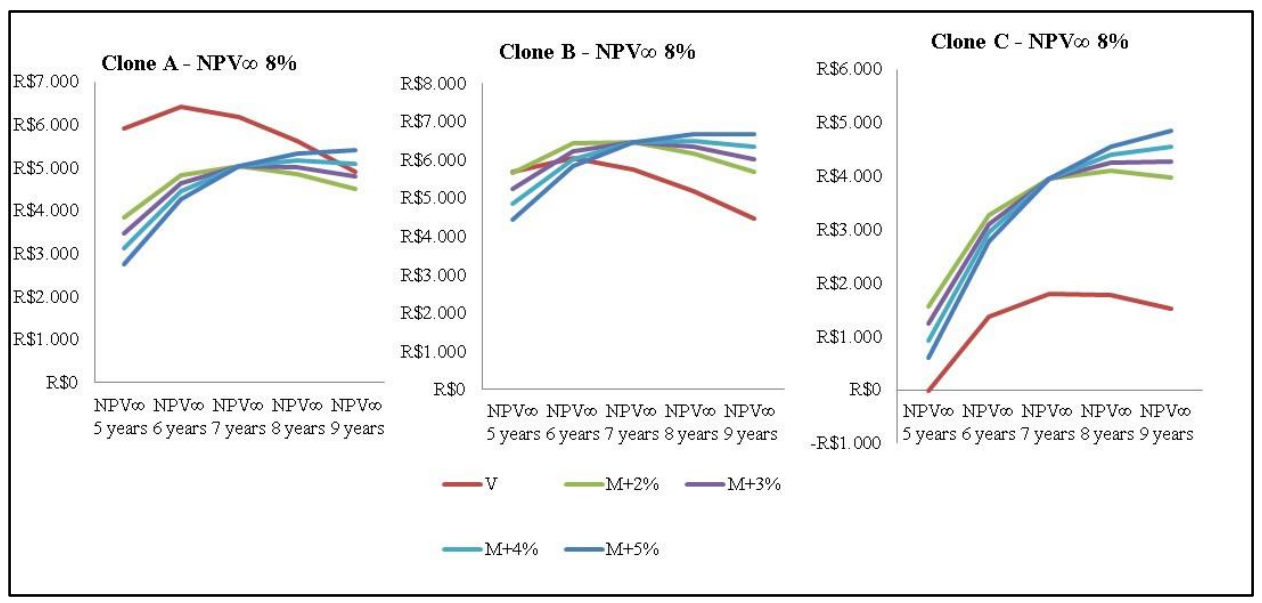

Figure 4. NPVœ considering an interest rate of $8 \%$ for all clones.

Figura 4. VPL $\infty$ considerando a taxa de desconto de $8 \%$ para todos os clones.

The IRR criteria reached the same results as the other analyzes. Clone A obtained greater volumetric IRR than gravimetric IRR at all ages. Clones B and C, on the other hand, presented higher mass IRR when compared to volume IRR, except at 5 years for clone B which presents volume advantage over mass. Considering the highest IRR, the gravimetric cutting age always occurred after the age by volume (Table 5).

FLORESTA, Curitiba, PR, v. 49, n. 4, p. 597 - 606, out/dez 2019.

Coelho, P. D. et.al.

ISSN eletrônico 1982-4688

DOI: $10.5380 /$ rf.v49 i4.52043 
Table 5. Internal Return Rate by volume and mass for all clones.

Tabela 5. Taxa Interna de Retorno por volume e massa para todos os clones.

\begin{tabular}{ccccccc}
\hline \multirow{2}{*}{ Year } & \multicolumn{2}{c}{ Clone A } & \multicolumn{2}{c}{ Clone B } & \multicolumn{2}{c}{ Clone C } \\
\cline { 3 - 5 } & IRR volume (A) & IRR mass (A) & IRR volume(B) & IRR mass (B) & IRR volume (C) & IRR mass (C) \\
\hline 5 & $\mathbf{1 6 . 9 7 \%}$ & $13.60 \%$ & $\mathbf{1 6 . 6 7 \%}$ & $16.09 \%$ & $7.96 \%$ & $10.12 \%$ \\
6 & $16.81 \%$ & $\mathbf{1 4 . 6 6 \%}$ & $16.40 \%$ & $\mathbf{1 6 . 5 9 \%}$ & $10.16 \%$ & $12.66 \%$ \\
7 & $15.86 \%$ & $14.60 \%$ & $15.41 \%$ & $16.16 \%$ & $\mathbf{1 0 . 6 3 \%}$ & $\mathbf{1 3 . 3 6 \%}$ \\
8 & $14.72 \%$ & $14.11 \%$ & $14.28 \%$ & $15.43 \%$ & $10.43 \%$ & $13.32 \%$ \\
9 & $13.60 \%$ & $13.50 \%$ & $13.17 \%$ & $14.63 \%$ & $9.97 \%$ & $12.98 \%$ \\
\hline
\end{tabular}

Source: Search Results. Bold means the highest IRR per volume or mass for each clone.

\section{DISCUSSION}

In relation to Graph 1, given that the charcoal steel industry and those that use forest biomass as a source of thermal energy have increasingly required raw material with high energy density, it is noted that the higher the wood density, ceteris paribus, the better it will be, because industries can boost their processes when they receive fuel with higher basic density, which would reduce the charcoal logistics costs (larger mass by the same volume) and increase the ore reduction in the blast furnace - more carbon by the same volume.

Therefore, even if clone $\mathrm{B}$ represents higher mass productivity than clone $\mathrm{C}$, this in turn will produce biomass with higher energy density. Though, for clone $\mathrm{C}$ to be preferred by producers, consumer industries should adopt a differentiated policy for its purchase, in addition to adopting the gravimetric unit.

Based on the results of Table 3, it was observed that the greater the increase in density, regardless of the MAI, the later the technical cutting age. It should also be taken into account that the increase in density does not occur linearly or throughout the tree's life, so it is necessary a critical analysis of the data to not have a misinterpretation and to conclude that the older the planting, the higher the profit if the sale of wood is in mass (R\$/ton).

In addition, there are other variables that should be considered when identifying the optimal cutting age. Diameter, for example, is an important variable, since larger diameter leads to more difficulty in drying wood, and also generates a higher heartwood percentage, which leads to the production of a more friable charcoal. Moisture content also negatively influences wood quality for energy, as the presence of water in wood generates reduction of its calorific value, causing difficulties in the carbonization and combustion control (SANTOS et al., 2016).

Thus, it may be understood that the adoption of the gravimetric unit of measurement in the forest sector tends to cause significant changes in project management, forest management, choice of genetic material and the commercialization of forest products.

As can be seen in Table 4, for the largest increments of basic density, it was observed that the cutting age tended to be further postponed. Considering the $5 \%$ increase in density per year, the economic cutting age at eight and nine years prevailed for all clones at all discount rates, and clone $\mathrm{C}$ presented negative NPV $\infty$ at $14 \%$. Thus, it was found that the NPVळ is directly related to the increase in density, because the higher the increment, the greater the NPVo.

In addition to the gravimetric NPV $\infty$ being higher than the volumetric NPV $\infty$ in absolute terms for denser clones (B and $\mathrm{C}$ ), the cutting age was postponed when the analysis was performed with the gravimetric unit, especially at low interest rates.

Therefore, in a market crisis situation, when prices are below the prevailing prices, or when there are no potential buyers, it is not advisable to follow the cutting rule by assessing only the economic age, even if there are no considerable volume gains, the mass gains are worth waiting for another year at all the simulated interest rates in this paper.

The results obtained in this work bring to the discussion of the fuel quality, because comparing clone A with $\mathrm{B}$, the choice will be for clone $\mathrm{B}$ given its mass productivity. Considering the mass productivity and financial profitability, clone B would also be chosen compared to $\mathrm{C}$, even though the density of clone $\mathrm{C}$ is $11.15 \%$ higher than clone B.

Regarding the wood market for charcoal production, it is desirable that the wood presents a high basic density, because for a certain furnace volume, the use of denser wood results in higher mass production (NEVES et al., 2011). This leads to the production of higher density charcoal and may encourage the production of higher basic density clones such as clones $\mathrm{B}$ and $\mathrm{C}$ presented in this work.

FLORESTA, Curitiba, PR, v. 49, n. 4, p. 597 - 606, out/dez 2019 Coelho, P. D. et.al. 
Therefore, in order to encourage the sale of denser wood, the forestry energy market must remunerate the one that produces wood with higher basic density, since the sensitivity simulations presented in this paper showed that, through economic analysis, the wood sales by mass for higher density clones has led to the economic viability.

This work understands that this incentive (differentiated remuneration) will only be effective if the change occurs vertically from the industry to the producers, which would give incentives to the forest producers to change the structure of their forests: replacing leafy forest plantations, with significant dimensions, but light, for forests with smaller diameters, but with mass as expressive as the dimensions of the old forests, directly implying in the genetic material choice and in the forest management.

\section{CONCLUSIONS}

Based on the results obtained, it was possible to conclude that:

- The wood basic density influenced the determination of the optimal cutting age.

- The cutting age, when analyzed in the gravimetric unit, occurred at least one year after the cutting age considering the volumetric unit.

- Lower density clones were technically and economically unviable for forest biomass' energy projects, considering the gravimetric unit analysis.

- Considering the change in the wood market from volumetric to gravimetric unit it was possible to verify that there are no economic losses in postponing the cutting age for one or two years, until the interest rate of $10 \%$, mainly in plantations with high incremental density rates.

\section{REFERENCES}

CAMPOS, J. C. C.; LEITE, H. G. Mensuração florestal: perguntas e respostas. 4 ed. Viçosa: UFV, 2013. 605p.

CARNEIRO, A. C. et al. Potencial energético da madeira de Eucalyptus sp. em função da idade e de diferentes materiais genéticos. Revista Árvore, v. 38, n. 2, p. 375-381, 2014.

CORDEIRO, S. A.; SILVA, M. L.; JACOVINE, L. A. G.; VALVERDE, S. R.; SOARES, N. S. Contribuição do fomento do órgão florestal de Minas Gerais na lucratividade e na redução de riscos para produtores rurais. Revista Árvore, v. 34, n. 2, p. 367-376, 2010.

EPE, EMPRESA DE PESQUISA ENERGÉTICA. Energia Renovável - Hidráulica, Biomassa, Eólica, Solar, Oceânica. Rio de Janeiro: 2016.

GOLFARI, L. Zoneamento ecológico do Estado de Minas Gerais para reflorestamento. Belo Horizonte: PNUD/FAO/IBDF-BRA/71/545, 1975. 65p. (Série Técnica 3).

INDÚSTRIA BRASILEIRA DE ÁRVORES - IBÁ. Relatório Anual. Brazilian Tree Industry, v. 53, n. 9, p. 100, 2016.

NASCIMENTO, M. D.; BIAGGIONI, M. A. M. Avaliação energética do uso de lenha e cavaco de madeira para produção de energia em agroindústria seropédica. Revista Energia na Agricultura, v. 25, n. 3, p. 104-117, 2010.

NEVES, T. A.; PRotásio, T. P.; COUTO, A. M.; TRUGIlho, P. F.; SIlVA, V. O.; VIEIRA, C. M. M. Avaliação de clones de Eucalyptus em diferentes locais visando à produção de carvão vegetal. Pesquisa Florestal Brasileira, v. 31, n. 38, p. 319-330, 2011.

PAINEL FLORESTAL. 10 Tendências para Negócios e Mercado Florestal em 2018. Disponível em $<$ http://www.painelflorestal.com.br/noticias/mercado/10-tendencias-para-negocios-e-mercado-florestal-em2018> Acesso em: 13 mai. 2018.

REZENDE, J. L. P.; OLIVEIRA, A. D. Análise Econômica e Social de Projetos Florestais. Viçosa, MG: UFV, 2001. 389 p.

REZENDE, J. L.; OLIVEIRA, A. D. Problemas com o horizonte de planejamento na avaliação de projetos florestais. Revista Árvore, Viçosa, v.24. n.2, abril/junho: 2000.

SANTOS, R. C.; CARNEIRO, A. C. O.; VITAL, B. R.; CASTRO, R. V. O.; VIDAURRE, G. B.; TRUGILHO, P. F.; CASTRO, A. F. N. M. Influência das propriedades químicas e da relação siringil/guaiacil da madeira de eucalipto na produção de carvão vegetal. Revista Ciência Florestal, Santa Maria, v. 26, n. 2, p. 657-669, 2016.

FLORESTA, Curitiba, PR, v. 49, n. 4, p. 597 - 606, out/dez 2019.

Coelho, P. D. et.al.

ISSN eletrônico 1982-4688

DOI: $10.5380 /$ rf.v49 i4.52043 
SILVA, M. L.; FONTES, A. A. Discussão sobre os critérios de avaliação econômica: valor presente líquido (VPL), valor anual equivalente (VAE) e valor esperado da terra (VET). Revista Árvore, Viçosa, v. 29, n. 6, dez. 2005.

SILVA, M. L.; JACOVINE, L. A. G.; VALVERDE, S. R. Economia Florestal 2.ed.-Viçosa: UFV, 2005.

TORRES, C. M. M. E.; OLIVEIRA, A. C.; PEREIRA, B. L.; JAVOCINE, L. A.; OLIVEIRA NETO, S. N.; CARNEIRO, A. C. Estimativas da produção e propriedades da madeira de eucalipto em Sistemas Agroflorestais. Scientia Forestalis, v. 44, n. 109, p. 137-148, 2016.

TRUGILHO, P. F.; LIMA, J. T.; MENDES, L. M. Influência da idade nas características físico-químicas e anatômicas da madeira de Eucalyptus saligna. Revista Cerne, Lavras, v. 2, n. 1, p. 1-15, 2009.

TRUGILHO, P.; SILVA, D. da. Influência da temperatura final de carbonização nas características físicas e químicas do carvão vegetal de jatobá (Himenea courbaril L.). Scientia Agraria, v. 2, n. 1-2, 2001. Universidade Federal do Paraná, Paraná, Brasil.

VALE, A. T. et al. Potencial energético da biomassa e carvão vegetal do epicarpo e da torta de pinhão manso (Jatropha curcas). Revista Cerne, v. 17, n. 2, p. 267-273, 2011.

VALVERDE, S. R.; RENTE, J.; VALVERDE, E. Estratégias e Mecanismos de Abastecimento da Indústria de base Florestal. SEBRAE, 2014.

VITAL, B. R.; CARNEIRO, A. C.; PEREIRA, B. L. Qualidade da madeira para fins energéticos. In: SANTOS, F. (Ed.). . Bioenergia e Biorrefinaria: cana de açúcar e espécies florestais. Viçosa: Os Editores, 2013. p. 322354. 